\title{
REVISTA
}

\section{EVALUATION OF THE INCORPORATION OF MARBLE AND GRANITE CUTTING RESIDUES IN CONCRETE FOR THE PRODUCTION OF INTERLOCKING PAVING FLOORS}

\author{
${ }^{1}$ Wandercleiton Cardoso* \\ ${ }^{2}$ Raphael Colombo Baptista \\ ${ }^{3}$ Thiago Augusto Pires Machado \\ ${ }^{4}$ André Gustavo de Sousa Galdino \\ ${ }^{5}$ Renzo di Felice

\begin{abstract}
${ }^{1}$ Università degli Studi di Genova. E-mail: wandercleiton.cardoso@dicca.unige.it
${ }^{2}$ Instituto Federal do Espírito Santo. E-mail: colombo.raphael@hotmail.com

${ }^{3}$ Instituto Federal do Espírito Santo. E-mail: thiagoaugustopn@yahoo.com.br

${ }^{4}$ Instituto Federal do Espírito Santo. E-mail: andregsg@ifes.edu.br

${ }^{5}$ Università degli Studi di Genova. E-mail: renzo.difelice@unige.it
\end{abstract} \\ *Autor de correspondência
}

Article submitted: 05/08/2021, accepted: 07/16/2021 and published 08/31/2021.

\begin{abstract}
Construction civil is an activity that consumes a large amount of natural resources. In the current scenario, it is important to look into sustainable development and to find alternatives for reusing solid waste. In this context, the reuse of marble and granite waste in the production chain is an alternative to mitigate a serious environmental problem as the consumption of decorative stones is increasing and the amount of waste produced is increasing. Due to the large amount of granite waste produced and not reused, this technical paper evaluates the technical feasibility of its use as a mixture for concrete and for the production of composite stones with a minimum compressive strength of 35 $\mathrm{MPa}$ and a maximum water absorption of $6 \%$ according to the regulatory requirements. The raw materials were characterized in terms of specific gravity, unit mass, particle size distribution, powdery materials and chemical composition. Then, the specimens were molded according to the requirements of the technical standard NBR 9781:2013 and the mechanical performance (compressive strength) and water absorption were analyzed. The results of the experimental program showed that the use of marble and granite waste as concrete aggregate for the production of pavements for pedestrians, light vehicles and commercial vehicles is technically feasible for pedestrian traffic, light vehicles and commercial vehicles.
\end{abstract}

Keywords: granite; marble; concrete; chemical properties; mechanical properties. 


\section{INTRODUCTION}

Construction civil is an activity that consumes a large amount of natural resources. In the current scenario, it is important to address sustainable development and to find alternatives for reusing of solid waste, as currently a significant amount of waste is generated, causing difficulties in storage, handling, transport and final destination, as well as burdens on the producer and environmental problems.

In this context, the reuse of marble and granite waste (RMGW) in the production chain is an alternative to alleviate a serious environmental problem (ARUNTAS et al., 2010; THAKUR et al., 2018; LI et al., 2018a; AWAD et al., 2020).

The urban area concentrates the largest population agglomerations and the largest extraction of natural resources, with the construction industry responsible for the consumption of $75 \%$ of these resources on the planet (MEDINA et al., 2018).

In Brazil, about 210 million tons of natural aggregates are consumed annually for the production of mortar and concrete. This gigantic demand depletes the reserves of raw materials near these urban centers, increasing energy consumption, pollution, production costs and the cost of transporting these materials over long distances (MONTANI, 2017; CHIODI, 2018).

The ornamental stone industry moves significant volumes in national and international markets. The reported world production of ornamental and facing stones evolved from 1.8 million tons per year in the 1920 s to 145 million tons in 2016 , with about 53.5 million tons of raw and processed stones sold on the international market in 2016, representing 790 million $\mathrm{m}^{2}$ equivalent of $2 \mathrm{~cm}$ thick slabs. (MONTANI, 2017; CHIODI, 2018).
In 2016, 8.5 million tons were produced in Brazil, distributed among marble, travertine, granite and similar rocks, generating about 2.1 million tons of waste from this processing, i.e. $25 \%$ of marble and granite waste (CHIODI, 2018).

The processing of the rock, when it is cut into $20 \mathrm{~mm}$ thick slabs, generates about 20 to $30 \%$ of the waste in the form of sludge, which is often left in nature or thrown into rivers and streams without proper treatment (CHIODI, 2018).

The states of Espírito Santo and Minas Gerais are the largest Brazilian producers and exporters, followed by Bahia and Ceará. In 2016, Brazil was the fourth largest producer in the world, while Italy ranked 6th with a $26 \%$ lower production compared to Brazilian production, producing a total of 6.52 million tons (CHIODI, 2018).

Italian dimension stone (marble) companies are mainly located in the traditional regions of Lucca, Massa, Carrara and Verona. The port of Carrara, equipped with special facilities for the loading, unloading and storage of stone, is an important element of the production and marketing infrastructure of this sector, since almost half of the foreign trade of decorative stones passes through it (MONTANI, 2017; CHIODI, 2018).

The consumption of decorative stones has increased and so has the amount of waste produced. This considerable amount of waste shows the importance of their use in construction, because they have a wide range, and consume large amounts of natural raw materials and, also, have a high fineness, which is very compatible with cement matrices and can be used as fillers in mortars and concrete (AYDIN et al., 2019; BAGHEL et al., 2020; JAIN et al., 2020).

In this context, and due to the large amount of granite cutting waste generated 
and not recycled, this technical article evaluates the technical feasibility of its use as an additive in concrete and for the production of composite blocks with a minimum compressive strength of $35 \mathrm{MPa}$ and a water absorption of no more than $6 \%$, as provided in the technical standard NBR 9781 (ABNT, 2013).

\section{CONTEXTUALIZATION}

The purpose of processing marble and granite is to convert the blocks obtained in the quarrying phase into finished or semi-finished products.

In the quarrying phase, the blocks are extracted in large dimensions, while in the primary processing phase, the blocks are prepared and sawn into slabs of different thicknesses, usually two or three centimeters, and subjected to surface treatment with or without resination, which may be a simple roughing, polishing, brushing and flaming, and the last processing step involves the production of tiles (AWAD et al., 2019a; AZEVEDO et al., 2019).

Marble and granite are commonly used in architecture and construction, but marble and granite are only some of the types of rocks used in civil construction. Rocks are solid natural aggregates composed of one or more minerals and are classified into three groups: igneous, metamorphic, and sedimentary (LI et al., 2019; MATOS et al., 2020; NASCIMENTO et al., 2020).

Magmatic rocks are formed by the consolidation of magma in the Earth's crust, which can be intrusive or extrusive. Intrusive igneous rocks are formed when consolidation in the Earth's subsurface is slow and there is enough time for minerals to grow and become easily visible, as in the case of granite, which is composed of quartz, feldspar, mica, and amphibole (LI et al., 2018b ; ZANELATO et al., 2020; SALMAN et al., 2021).
However, when volcanic lava solidifies at the Earth's surface, it cools rapidly, preventing the crystals from developing and creating extrusive igneous rocks such as basalt. Dark igneous rocks are rich in minerals such as magnesium and iron, while light-colored rocks are rich in silicon and aluminum.

It is important to know the chemical composition of granite when making concrete and mortar, as elements such as magnesium may cause expansion during curing, leading to cracking when used in coatings and pavements. In addition, the fineness of the residue and the $\mathrm{SiO}_{2}$ content associated with the production process may have a high reactivity, leading to the occurrence of alkali aggregate reactions (LI et al., 2019; MESSAOUDA et al., 2019).

Metamorphic rocks are formed by the transformation of pre-existing rocks under conditions of temperature and pressure. Depending on the geological events in each region, such as mountain ranges, their structure varies. Marble, an example of a metamorphic rock, is mainly composed of calcite (BINCI et al., 2007; TORRES et al., 2009).

Sedimentary rocks formed by the deposition of debris from other rocks, igneous or metamorphic rocks, the accumulation of organic debris, or even chemical precipitation include sandstone and limestone (BILGIN et al., 2012).

During the quarrying process, the rocks are cut into slabs which are used in various fields of civil construction. This process produces wastes characterized by the type of rock quarried such as marble, granite, sandstone and other rocks. (INCE et al., 2020)

The production cycle of ornamental stone involves three basic steps: the extraction or quarrying of rocks with dimensions of approximately $3.0 \times 2.0 \times$ $1.5 \mathrm{~m}$, followed by primary processing, where the blocks are sawn into slabs with 
approximate dimensions of $2.80 \times 1.90 \times$ $0.02 \mathrm{~m}$ using looms, and at the end of the production cycle is secondary processing, which takes place in finishing industries, where finishing is carried out according to customer requirements (MONTANI, 2017).

In the primary processing industry, for every cubic meter of rock sawn on the looms, an average of $32 \mathrm{~m}^{2}$ of $2 \mathrm{~cm}$ thick slabs or $49 \mathrm{~m}^{2}$ of $1 \mathrm{~cm}$ thick slabs are produced. The looms used are made of diamond wire or metal blades. In the former case the residue consists of rock dust and water, but when looms with metal blades are used, which is most frequently the case, the sludge produced consists of water, lime, grist, and fragments of metal from the blades themselves.

This slurry flows into the collection tank, is circulated through the looms by centrifugal pumps, and is continuously sprayed onto the cutting surface to unclog the channels between the blades and facilitate sawing. The blades are also lubricated and cooled to prevent their oxidation (MAHESH et al., 2021)

The waste generated from cutting the rock is also generated in the extraction industry (quarries). Once the blocks are quarried, they are sawn on the looms in the primary processing stage and later when the slabs are processed in the secondary processing stage (marble works), where the raw slabs are cut into smaller pieces, i.e. marble and granite waste is generated throughout the production chain.

In secondary processing (marble works), saws with diamond-tipped metal disks are used and the waste produced is very diverse, so its physical, chemical and mineralogical characterization is essential to be used in new products (MARTINI et al., 2018).

As for the treatment of the waste generated in the production chain from the more viscous fraction of the sludge, it is usually sent to decanting basins or press filters to reduce its moisture.

These wastes are then transported and disposed in landfills without prior treatment. In numerous cases, these wastes are also deposited in rivers, streams or sewers, leading to siltation of rivers and contamination of groundwater, causing conflicts between environmental authorities and the adjacent population (MASHALY et al., 2018).

In order to minimize the impact on the environment, companies build wastewater treatment plants, such as decanting boxes, so that the residues can be used for various purposes, such as raw material for concrete and mortar.

The chemical composition of marble and granite cutting waste (MGCW) is diverse. Generally, the waste consists of silica $\left(\mathrm{SiO}_{2}\right)$, alumina $\left(\mathrm{Al}_{2} \mathrm{O}_{3}\right)$, lime $(\mathrm{CaO})$ and alkali oxides $\left(\mathrm{Na}_{2} \mathrm{O}, \mathrm{K}_{2} \mathrm{O}\right)$, but there is also iron oxide ( $\mathrm{Fe} 2 \mathrm{O} 3)$, which may be present in greater or lesser amounts due to the wear of the cutting blades (GHALEHNOVI et al., 2019).

Table 1 illustrates the chemical compounds formed during the cutting of marble and granite. In each case, the abbreviations mean: Marble Waste (MW), Granite Waste (GW), Marble and Granite Waste (MGW), Ornamental Stone Waste (OSW), Marble Cut Waste (MCW), Cutting Waste Granite (CWG), Marble and Granite Cutting Waste (MGCW), Marble and Granite Processing Waste (MGPW) and Ornamental Stone Processing Waste (OSPW).

The reported world production of decorative stone, including marble and granite, developed from 1.8 million $\mathrm{t} / \mathrm{y}$ in the 1920 s to 145 million $\mathrm{t} / \mathrm{y}$ in 2016 , with about 53.5 million $t$ of raw and processed stone sold in the international market, representing 790 million $\mathrm{m}^{2}$ equivalent of $2 \mathrm{~cm}$ thick slabs.

Table 2 shows the major producing, exporting and importing countries in the 
world. Analyzing Table 2, it is shown that China was the world's leading producer of natural stone in 2016, and countries such as Brazil, the fourth largest producer, and Italy, the sixth largest producer, accounted for more than $10 \%$ of the world's production of decorative stone.
There is also a significant increase in world production, exponentially due to the wide variety of decorative stone found mainly in countries such as China, India, Brazil and Italy, such as marble, granite, slate, quartzite and travertine (MONTANI, 2017; CHIODI, 2018 ).

Table 1: Chemical composition of marble and granite waste (\%)

\begin{tabular}{|c|c|c|c|c|c|c|c|c|c|}
\hline Compounds & $\begin{array}{c}\text { MW } \\
\text { (1) }\end{array}$ & $\begin{array}{c}\text { GW } \\
\text { (2) }\end{array}$ & $\begin{array}{c}\text { MGW } \\
\text { (3) }\end{array}$ & $\begin{array}{c}\text { OSW } \\
\text { (4) }\end{array}$ & $\begin{array}{c}\mathrm{MCW} \\
(5)\end{array}$ & $\begin{array}{c}\text { CWG } \\
\text { (6) }\end{array}$ & $\begin{array}{c}\text { MGCW } \\
\text { (7) }\end{array}$ & $\begin{array}{c}\text { MGPW } \\
\text { (8) }\end{array}$ & $\begin{array}{c}\text { OSPW } \\
\text { (9) }\end{array}$ \\
\hline $\mathrm{SiO}_{2}$ & 0.67 & 67.91 & 48.3 & 63.23 & 8.1 & 59.62 & 70.4 & 54.62 & 23.4 \\
\hline $\mathrm{Al}_{2} \mathrm{O}_{3}$ & 0.12 & 13.13 & 10.76 & 15.34 & 0.7 & 12.77 & 15.2 & 9.71 & 4.32 \\
\hline $\mathrm{Fe}_{2} \mathrm{O}_{3}$ & 0.08 & 1.97 & - & 3.53 & 0.7 & 9.49 & 2.0 & 5.86 & 2.83 \\
\hline $\mathrm{CaO}$ & 54.43 & 2.98 & 16.53 & 3.34 & 44.3 & 4.83 & 1.0 & 20.12 & 64.5 \\
\hline MgO & 0.59 & 0.51 & 0.78 & 0.34 & 5.6 & 1.96 & 0.35 & 3.22 & 1.73 \\
\hline $\mathrm{Na}_{2} \mathrm{O}$ & 0.14 & 4.69 & 3.73 & 3.04 & 0.01 & 2.72 & 3.7 & 2.15 & 0.79 \\
\hline $\mathbf{K}_{2} \mathbf{O}$ & 0.02 & 3.91 & 4.43 & 5.34 & 0.03 & 5.3 & 5.5 & 3.74 & 1.04 \\
\hline $\mathrm{SO}_{3}$ & 0.01 & 0.01 & 0.25 & 1.52 & 0.04 & 0.03 & 0.01 & 0.12 & 0.47 \\
\hline Others & 0.54 & 1.98 & 3.49 & 2.98 & 0.02 & 1.36 & 084 & 0.06 & 0.62 \\
\hline Loss on ignition & 43.4 & 2.91 & 11.73 & 1.34 & 40.5 & 1.92 & 1.0 & 1.0 & 0.30 \\
\hline
\end{tabular}

Source: (1) Aruntas et al. (2010); (2) Chen et al. (2020); (3) Awad et al. (2019b); (4) Azevedo et al. (2020); (5) Aydin et al. (2019); (6) Gonçalves (2000); (7) Lopez et al. (2020); (8) Zanelato et al. (2020); (9) Ince et al. (2020).

Table 2: World's leading producers of ornamental stones (2013-2016)

\begin{tabular}{lrrrrrrrr}
\hline \multirow{2}{*}{$\begin{array}{c}\text { Countries x } \\
\text { Year (Weight) }\end{array}$} & \multicolumn{2}{c}{$\mathbf{2 0 1 3}$} & \multicolumn{2}{c}{$\mathbf{2 0 1 4}$} & \multicolumn{1}{c}{$\mathbf{2 0 1 5}$} & \multicolumn{2}{c}{$\mathbf{2 0 1 6}$} \\
\hline China & 39.5 & \multicolumn{1}{c}{ \% } & \multicolumn{1}{c}{ Mt } & \multicolumn{1}{c}{ \% } & \multicolumn{1}{c}{ Mt } & \multicolumn{1}{c}{$\%$} & \multicolumn{1}{c}{ Mt } & \multicolumn{1}{c}{} \\
\hline India & 19.5 & 15,0 & 20.5 & 31.1 & 45.0 & 32.1 & 46.0 & 31.7 \\
\hline Turkey & 12.0 & 9,2 & 11.5 & 8.4 & 10.5 & 7.5 & 10.75 & 7.4 \\
\hline Brazil & 9.0 & 6,9 & 8.75 & 6.4 & 8.2 & 5.9 & 8.5 & 5.9 \\
\hline Iran & 6.5 & 5,0 & 7.0 & 5.1 & 7.5 & 5.4 & 8.0 & 5.5 \\
\hline Italy & 7.0 & 5,4 & 6.75 & 4.9 & 6.5 & 4.6 & 6.25 & 4.3 \\
\hline Egypt & 3.0 & 2,3 & 4.2 & 3.1 & 5.0 & 3.5 & 5.25 & 3.6 \\
\hline Spain & 5.0 & 3,8 & 4.85 & 3.6 & 4.75 & 3.4 & 5.0 & 3.4 \\
\hline USA & 2.75 & 2,1 & 2.65 & 1.9 & 2.7 & 1.9 & 2.8 & 1.9 \\
\hline Portugal & 2,65 & 2,0 & 2.75 & 2.0 & 2.7 & 1.9 & 2.6 & 1.8 \\
\hline France & 1.05 & 0,8 & 1.2 & 0.9 & 1.25 & 0.9 & 1.3 & 0.9 \\
\hline Saudi Arabia & 1.2 & 0,9 & 1.3 & 1.0 & 1.2 & 0.9 & 1.25 & 0.9 \\
\hline Greece & 1.25 & 1,0 & 1.3 & 1.0 & 1.25 & 0.9 & 1.2 & 0.8 \\
\hline Pakistan & 1,0 & 0,8 & 1.0 & 0.7 & 1.05 & 0.7 & 1.1 & 0.7 \\
\hline Subtotal & 111.4 & 85,6 & 115.75 & 84.8 & 118.6 & 84.6 & 123.5 & 85.0 \\
\hline Others & 18.6 & 14,3 & 20.75 & 15.2 & 21.4 & 15.7 & 21.5 & 15.0 \\
\hline Total & $\mathbf{1 3 0 . 0}$ & $\mathbf{9 9 . 0}$ & $\mathbf{1 3 6 . 5}$ & $\mathbf{1 0 0}$ & $\mathbf{1 4 0 . 0}$ & $\mathbf{1 0 0 . 3}$ & $\mathbf{1 4 5 . 0}$ & $\mathbf{1 0 0}$ \\
\hline & & Source: Montani $(2017) ;$ Chiodi $(2018)$. & & &
\end{tabular}


In Brazil alone, about 800,000 $\mathrm{t} /$ year of waste is generated and improperly disposed of in the environment, and few companies care about reducing the environmental impact of disposing of this waste in the environment, i.e., there is still no sustainable destination for waste from rock processing (MONTANI, 2017; CHIODI, 2018).

According to the literature, several authors study methods to reuse waste from the processing of ornamental stones to reintroduce them into the production chain, for example, in the production of mortar, the production of concrete, the production of ceramic blocks and the production of building blocks ( ERGÜN, 2011; KRSTULOVIĆ et al., 1994; LI et al., 2019).

Among the different applications for the reuse of marble and granite cut waste (MGCW), it is able to mention the production of concrete for the production of segmented pieces for construction and paving, as examples, ceramic blocks and interlocking floors.

Developed countries such as Italy, although they do not have paving problems, still depend on non-renewable products such as bitumen for paving public roads. In Brazil, on the other hand, more than $80 \%$ of roads in national parks are not paved (MONTANI, 2017; CHIODI, 2018).

The use of paving stones is a solution to this problem, since it is possible to use MGCW to produce these materials, solving this serious rural and urban problem. In addition, this type of paving favors the reduction of flooding in urban areas due to the higher infiltration rate and lower flow rate of precast concrete compared to asphalt, as well as low maintenance costs.

In Brazil, the use of concrete pavers must meet the normative requirement of NBR 9781 (ABNT, 2013). Table 3 illustrates the minimum resistance values according to the type of traffic required.

Table 3: characteristic compressive strength

\begin{tabular}{cc}
\hline Request & $\begin{array}{c}\text { Characteristic resistance to } \\
\text { compression at 28 days }\end{array}$ \\
\hline Pedestrian traffic, light vehicles and commercial vehicles & $\geq 35 \mathrm{MPa}$ \\
\hline $\begin{array}{c}\text { Traffic of special vehicles and requests capable of producing } \\
\text { accentuated abrasion effects }\end{array}$ & $\geq 50 \mathrm{MPa}$ \\
\hline
\end{tabular}

Source: ABNT NBR 9781 (2013, p.6).

\section{EXPERIMENTAL}

The raw materials were characterized in order to obtain the necessary information about their use. They were mainly marble and granite waste, whose composition was unknown for this study.

The raw materials were characterized by specific mass, unit mass, particle size distribution, powdery materials and chemical composition (FRX).
Then, the specimens were shaped according to the requirements of the respective test standards and analyzes of mechanical performance and durability were performed in their different properties.

\subsection{Cement}

The cementitious binder used was the sulfate resistant Portland cement with high initial strength (CPV ARI- RS). The fineness was determined according to the standard NBR 11579 "Portland Cement Determination of fineness index by a $75 \mu \mathrm{m}$ sieve" (ABNT, 2012). 
Permeability was determined according to the standard NBR 16372 "Portland cement and other powdery materials - determination of fineness by Blaine air permeability method" (ABNT, 2015). The beginning of the end of setting was determined according to standard NBR 16607 "Portland Cement Determination of setting times" (ABNT, 2018).

The actual cement density was determined using the Le Chatelier piston method in accordance with the standard NBR 16605 "Portland cement and other powdery materials - determination of specific mass" (ABNT, 2017).

The insoluble residue was determined by NBR NM 15, the sulfuric anhydride was determined by NBR NM 16 (ABNT, 2012), the loss on ignition was determined by NBR NM 18 (ABNT, 2012) and the sulfur content in the form of sulfide was determined by NBR NM 19 (ABNT, 2012), the determination of carbon dioxide content by gasometry using NBR NM 20 (ABNT, 2012), while the chemical composition was determined using the technique of X-ray fluorescence spectroscopy (FRX) and based on the standard NBR NM 14 (ABNT, 2012).

\section{2 aggregates}

The fine aggregate of quartz origin was previously washed and dried in a kiln at a temperature of about $105 \pm 1{ }^{\circ} \mathrm{C}$, sieved through a \#6.3 $\mathrm{mm}$ screen, and stored in ceramic vats before being tested and shaped. The specific mass of the sand was determined using the Chapman piston method in accordance with NBR 16916 "Mini-Aggregates - Determination of the specific mass and apparent specific mass" (ABNT, 2021).

The aggregate used (gneiss) of diabasic origin was washed, dried and sieved using the fraction that passed through the $\# 19 \mathrm{~mm}$ sieve and was retained in the \#6.3mm sieve. The specific mass of the gravel was determined using the hydrostatic balance method in accordance with NBR 16917 "Coarse aggregates Determination of specific mass, apparent specific mass and water absorption" (ABNT, 2021). The aggregates were also tested in accordance with NBR 7211 "Aggregates for concrete - Specification" (ABNT, 2019).

\subsection{Marble and granite cutting waste}

The waste from the processing stage was collected from ornamental stone marketers and then exposed to sunlight, dried in an oven at a temperature of about $105 \pm 1^{\circ} \mathrm{C}$, and then sieved (75 $\mu \mathrm{m}$ fine), homogenized, quartered, and stored in a dry place.

The chemical composition was determined by X-ray fluorescence spectroscopy (FRX). X-ray fluorescence (XRF) is an analytical technique that can be used to determine the chemical composition of a variety of sample types, including solids, liquids, pastes, and loose powders. X-ray fluorescence is also used to determine the thickness and composition of layers and coatings.

\subsection{Concrete dosage (test specimens)}

The concrete was mixed with a mass ratio of 1:0.8:1.2 (binder, sand, gravel 0) and a water/binder ratio of 0.3 , where binder $=$ cement + MGCW, with a reduction of the truncated cone in the fresh state of $12 \pm 2 \mathrm{~cm}$.

In order to improve the workability of the prepared concrete, $2.2 \mathrm{~kg} / \mathrm{m}^{3}$ of Muraplast FK 830 multifunctional plasticizer with normal setting was added, which reduces the surface tension of the mixing water and improves compaction when the cement particles are well dispersed.

The MGCW was replaced by cement in the amounts of $0 \%(\mathrm{~S} 0) ; 5 \%$ (S5); 10\% (S10); 15\% (S15); and 20\% (S20), and the cement was reduced in the same weight ratio so that the mass of the mixture was 1:0.8:1.7 (cement + MGCW, sand, gravel 0). 
For the axial compression test, 20 specimens from each group were formed, making a total of 100 specimens. The specimens were formed according to NBR
5738 "Concrete: methods of forming and curing specimens" (ABNT, 2016). Table 4 illustrates the theoretical dosage per $\mathrm{m}^{3}$ of concrete produced.

Table 4: Concrete dosage

\begin{tabular}{ccccccc}
\hline Sample & $\begin{array}{c}\text { Cement } \\
\left(\mathrm{kg} / \mathrm{m}^{3}\right)\end{array}$ & $\begin{array}{c}\text { MGCW } \\
\left(\mathrm{kg} / \mathrm{m}^{3}\right)\end{array}$ & $\begin{array}{c}\text { Sand } \\
\left(\mathrm{kg} / \mathrm{m}^{3}\right)\end{array}$ & $\begin{array}{c}\text { Gravel } \\
\left(\mathrm{kg} / \mathrm{m}^{3}\right)\end{array}$ & $\begin{array}{c}\text { Water } \\
\left(\mathrm{kg} / \mathrm{m}^{3}\right)\end{array}$ & $\begin{array}{c}\text { Additive } \\
\left(\mathrm{kg} / \mathrm{m}^{3}\right)\end{array}$ \\
\hline S0 (standard) & 729 & - & 559 & 891 & 219 & 2.2 \\
\hline S5 & 692 & 37 & 559 & 891 & 219 & 2.2 \\
\hline S10 & 656 & 73 & 559 & 891 & 219 & 2.2 \\
\hline S15 & 619 & 110 & 559 & 891 & 219 & 2.2 \\
\hline S20 & 583 & 146 & 559 & 891 & 219 & 2.2 \\
\hline
\end{tabular}

Source: Prepared by the authors (2021).

\subsection{Water absorption test}

In this study, the Portland Cement CPV ARI- RS was used as a reference for the fabrication of the test specimens, which were demolded 24 hours after curing. The water absorption test was not performed for the specimens with an age of 1 day, as this age served as a reference for the other analyzes performed.

After demoulding, the samples were immersed in water at an average temperature of $25^{\circ} \mathrm{C}$ and taken for the absorption test after 3, 7, 21 and 28 days.

The samples were dried with a wire mesh to allow the water to drain for about 5 minutes. They were then dried with a damp cloth and weighed individually in the saturated state.

The pieces were allowed to rest for 4 hours and then weighed again to check the weight. None of the specimens tested showed a mass difference of more or less than $0.5 \%$ from the previously measured value.

The specimens were then oven dried for 24 hours at an average temperature of $105 \pm 1{ }^{\circ} \mathrm{C}$ and then reweighed. None of the samples showed a mass difference of more than $0.5 \%$ compared to the previous value.

\subsection{Axial compression test}

The specimens were molded in a cylindrical shape of $100 \mathrm{~mm} \times 200 \mathrm{~mm}$ as per NBR 5738 (2016), filled with concrete in two successive layers and lifted 12 times each with the consolidation bar.

The specimens were ground and fractured at the age of 1, 3, 7, 21 and 28 days under continuous application of force and without impact on the fracture point.

The axial compression test was carried out in accordance with the standard NBR 5739 "Concrete - Compression test on cylindrical specimens" (ABNT, 2018).

\section{RESULTS AND DISCUSSION}

\subsection{Raw material characterization}

The chemical composition of cement and MGCW was evaluated using the X-ray fluorescence spectroscopy (FRX) technique and the results are shown in Table 5. 
Table 5: Chemical composition of cement and MGCW

\begin{tabular}{lcccccccccccc}
\hline & $\mathrm{SiO}_{2}$ & $\mathrm{Al}_{2} \mathrm{O}_{3}$ & $\mathrm{MgO}$ & $\mathrm{K}_{2} \mathrm{O}$ & $\mathbf{C a O}$ & $\mathrm{Fe}_{2} \mathrm{O}_{3}$ & $\mathrm{Na}_{2} \mathrm{O}$ & $\mathrm{TiO}_{2}$ & $\mathrm{P}_{2} \mathrm{O}_{5}$ & $\mathrm{SO}_{3}$ & $\mathrm{MnO}$ & \% LI \\
\hline CEMENT & 22.65 & 4.10 & $\mathbf{3 . 5 0}$ & 0.35 & 60.9 & 3.35 & 0.55 & - & - & $\mathbf{1 . 7 0}$ & - & $\mathbf{1 . 6 0}$ \\
\hline MGCW & 69.10 & 18.73 & $\mathbf{2 . 7 1}$ & 2.31 & 2.05 & 1.91 & 1.61 & 0.34 & 0.33 & $\mathbf{0 . 1 2}$ & 0.04 & $\mathbf{1 6 . 8}$ \\
\hline $\begin{array}{l}\text { Limit } \\
\text { NBR 16697 }\end{array}$ & - & - & $\leq 6,5$ & - & - & - & - & - & - & $\leq 4,5$ & - & $\leq 6,5$ \\
\hline
\end{tabular}

Source: Prepared by the authors (2021).

Analyzing Table 5, the results confirm the main constituents of Portland cement, such as calcium oxide $(\mathrm{CaO})$, silicon dioxide $\left(\mathrm{SiO}_{2}\right)$, aluminum oxide $\left(\mathrm{Al}_{2} \mathrm{O}_{3}\right)$, magnesium oxide $(\mathrm{MgO})$, iron oxide II $\left(\mathrm{Fe}_{2} \mathrm{O}_{3}\right)$, and sulfur trioxide $\left(\mathrm{SO}_{3}\right)$ in small amounts, in addition to other elements in small amounts, such as impurities, cement alkalis $\left(\mathrm{Na}_{2} \mathrm{O}\right.$, sodium oxide and $\mathrm{K}_{2} \mathrm{O}$, potassium oxide), and other minor substances such as titanium oxide $\left(\mathrm{TiO}_{2}\right)$.

The NBR 16697 standard (ABNT, 2018) stipulates that the content of sulfur trioxide $\left(\mathrm{SO}_{3}\right)$ must be less than $4.0 \%$ as it is an unstable corrosive compound and reacts with water, while the oxide content of magnesium $(\mathrm{MgO})$ must be less than
$6,5 \%$ as it slowly converts to magnesium hydroxide $\left(\mathrm{Mg}(\mathrm{OH})_{2}\right)$ during hydration in large quantities in the cement, which expands and generates internal stresses leading to cracking and crazing.

An analysis of Table 5 shows that the predominant compound in $\mathrm{MGCW}$ is silicon dioxide $\left(\mathrm{SiO}_{2}\right)$, followed by aluminum oxide $\left(\mathrm{Al}_{2} \mathrm{O}_{3}\right)$ and calcium oxide or free lime $(\mathrm{CaO})$, which account for more than $90 \%$ of the chemical composition of the compound.

The NBR 16697 standard (ABNT, 2018) specifies that the loss on ignition (LI) after heating to $1000^{\circ} \mathrm{C}$ must be less than $6.5 \%$ by mass. The results of physical characterization of cement, sand, gravel and MGCW are shown in Table 6.

Table 6: Chemical composition of cement and MGCW

\begin{tabular}{lccccc}
\hline \multicolumn{1}{c}{ Characteristics } & Cement & Sand & Gravel & MGCW & Unit \\
\hline Fineness module & - & 1.800 & - & - & $\mathrm{kg} / \mathrm{dm}^{3}$ \\
\hline Powdery material & - & 1.300 & - & - & $\%$ \\
\hline Max. dimension feature & - & 2.360 & 6,3 & - & $\mathrm{mm}$ \\
\hline Unit mass & - & 1.592 & 1.421 & - & $\mathrm{kg} / \mathrm{dm}^{3}$ \\
\hline Especific mass & 3.252 & 2.621 & 2.822 & 2.920 & $\mathrm{~kg} / \mathrm{dm}^{3}$ \\
\hline Average particle diameter & 0.050 & 0.600 & - & 0.012 & $\mathrm{~mm}$ \\
\hline Fineness $(\mathbf{7 5} \boldsymbol{\mu m}$ sieve residue) & 1.2 & - & - & - & $\%$ \\
\hline Setting times (start) & 204 & - & - & - & $\mathrm{min}$ \\
\hline Setting times $($ end) & 275 & - & - & - & $\mathrm{min}$ \\
\hline Carbonic anhydride $\left(\mathbf{C O}_{2}\right)$ & 2.1 & - & - & - & $\%$ \\
\hline Blaine Permeability & 4186 & - & - & - & $\mathrm{cm}^{2} / \mathrm{g}$ \\
\hline Insoluble waste & 0.56 & - & - & - & $\%$ \\
\hline
\end{tabular}

Source: Prepared by the authors (2021).

Based on the test results in Table 6, which refer to the physical characterization of the materials in this study, it can be seen that all the results are within the limits specified in the regulatory standards. 
However, for the binder of MGCW, there are no values specified in the standard.

\subsection{Axial compression test}

Figure 1 shows the average results of pressure testing at 1,7 , and 21 days of age. Analyzing Figure 1, it was found that the sample with addition of $20 \%$ MGCW instead of cement had the worst result among the analyzed samples. However, the strength values meet the normative requirements of NBR 9781 (ABNT, 2013) and are suitable for use in pedestrian traffic, light vehicles and commercial vehicles as they have a characteristic compressive strength of more than $35 \mathrm{MPa}$ after 28 days.
The strength loss with increasing addition of MGCW can be explained by the absorption of a greater amount of water than the cementitious binder, which increases the porosity that directly affects the strength loss in axial compression, a hypothesis that was confirmed in the analysis of the absorption content of water.

As can be seen in Figure 2, it was found that the water absorption of the S20 sample (20\% MGCW) after 28 days was about $60 \%$ higher than that of the standard S0 sample to which no cutting residues had been added.

Figure 1: Axial Compressive Strength Test Results

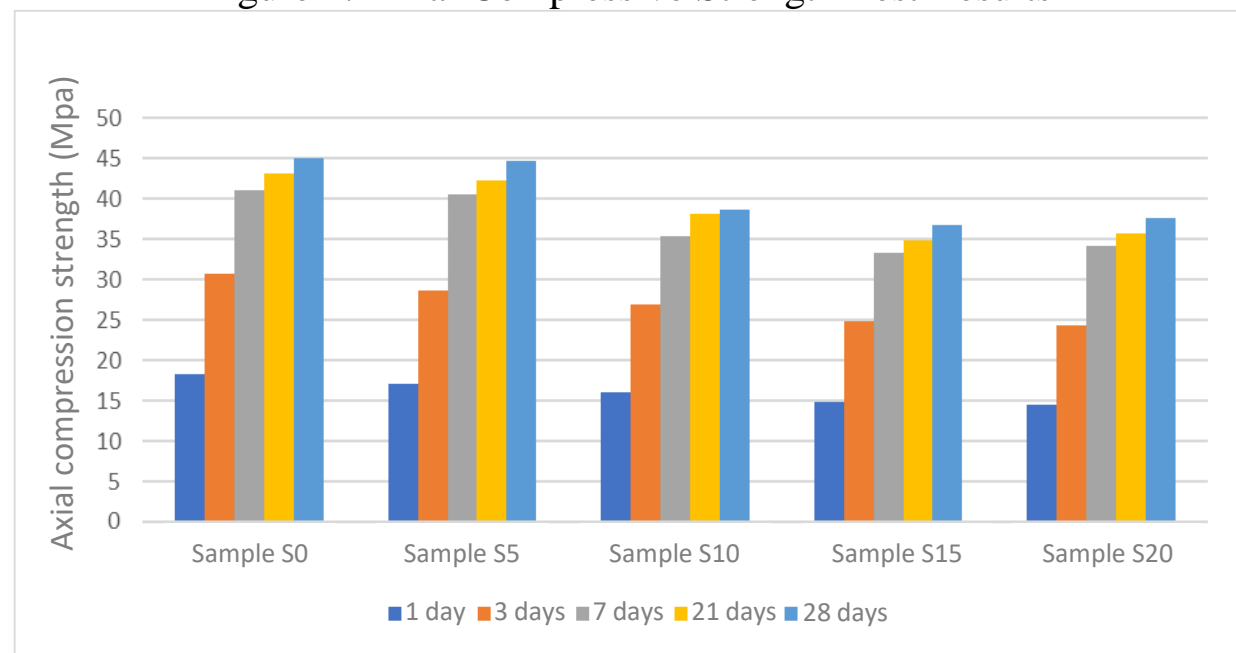

Source: Prepared by the authors (2021).

Figure 2: Water absorption test results

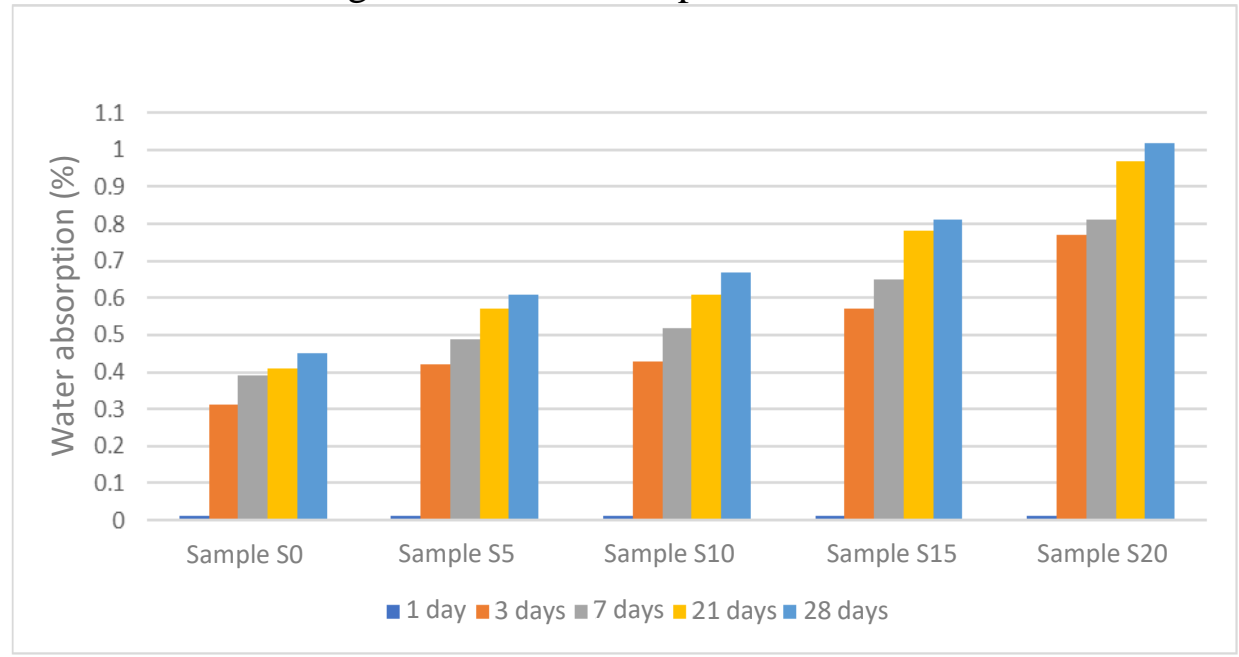

Source: Prepared by the authors (2021). 
The results of this study confirm the studies of other authors, such as Bilgin et al. (2012), who used MGCW in the production of industrial bricks with mass fractions ranging from $0-80 \%$. Bilgin et al. (2012) found that a replacement content of up to $10 \%$ MGCW did not change the mechanical properties of the manufactured bricks compared to the reference brick, but when more than $10 \%$ MGCW was added, there was an increase in water absorption.

Krstulovic et al. (1994) found that MGCW improved the axial compressive strength of concrete and mortar, especially at low residue levels, ranging from 5 to $6 \%$ of the cement mass, and concluded that this effect is more pronounced when the MGCW is very thin, as is the case with the residues used in this study.

Binici et al. (2007) used MGCW as a coarse aggregate and granulated blast furnace slag as a fine aggregate in the production of concrete and found a reduction in chloride penetration of about $70 \%$, with better cohesion between the constituents of the mix (admixture, cement and aggregate), suggesting that MGCW aggregates may also be used to improve mechanical properties and chemical resistance compared to conventional concrete.

The addition of granite cutter residue in concrete in proportions ranging from $10 \%$ to $20 \%$ with respect to the cement mass, keeping the water-cement ratio constant, showed greater cohesion and consistency, improved mechanical performance and increased resistance to axial compression between $8 \%$ and $19.6 \%$ for the proportions of $10 \%$ and $20 \%$, respectively.

In the study conducted by Ergün (2011), 5\% by weight of cement was replaced by marble and granite waste, which confirms that the replacement of cement with waste improves the mechanical properties of conventional concretes.

According to the literature, other studies have shown similar results when MGCW is replaced in amounts up to $20 \%$, although there are several divergent variables that should be considered, including the concrete mix, the type of cement used, and the use of MGCW as fine aggregate or senior (Bilgin et al., 2012).

However, the results of this study are confirmed by several authors who conclude that replacing the binder with MGCW in a proportion of up to $20 \%$ confirms the technical feasibility in terms of pedestrian, light vehicle and commercial vehicle use and reduces the production costs and environmental impact of disposing MGCW in landfills (BINICI et al., 2007; BILGIN et al., 2012).

\section{CONCLUSIONS}

Among the various ways to reduce the environmental impact of waste generation, recycling is the one with the greatest benefit. The construction sector offers the greatest potential for the use of waste due to the numerous processes that use different materials. Not only do they contribute to a more sustainable development.

Regarding the axial compressive strength, the addition of MGCW did not cause the concrete to perform better than the reference concrete, but the final result was above $35 \mathrm{MPa}$ for all specimens tested.

When analyzing the water absorption results, it was found that all specimens showed satisfactory results according to NBR 9781 (ABNT, 2013), which specifies a maximum water absorption of $6 \%$, with results ranging from $0.45 \%$ to $1 \%$ water absorption, as the specimen without the addition of residues showed the best result. 
According to the literature, cutting residues of marble and granite should preferably be used as a substitute for coarse and fine aggregates. However, depending on the final use of the concrete mix, the use of these residues instead of cement binder in an amount up to $20 \%$ can give satisfactory results.

In conclusion, from the results of the experimental program, it is technically feasible to use marble and granite waste as concrete aggregate and for the production of paving stones for the manufacture of interlocking pavements for pedestrian traffic, light vehicles and trucks.

\section{REFERENCES}

ARUNTAȘ, Hüseyin Yılmaz; GÜRÜ, Metin; DAYI. Mustafa; TEKIN, Ilker. Utilization of waste marble dust as an additive in cement production. Materials and Design, v.31, 2010, 4039-4042 p. https://doi.org/10.1016/j.matdes.2010.03.036

AWAD, A.H.; EL-WAHAB, Abd.; ELGAMSY, Ramadan; ABDEL-LATIF, Hazen. A study of some thermal and mechanical properties of HDPE blend with marble and granite dust. Ain Shams Engineering Journal, Volume 10, Issue 2, 2019a, Pages 353-358, https://doi.org/10.1016/j.asej.2018.08.005

AWAD, A.H.; EL-WAHAB, Abd.; ELGAMSY, Ramadan; ABDEL-LATIF, Hazen. Assessment of mechanical properties of HDPE composite with addition of marble and granite dust, Ain Shams Engineering Journal, Volume 11, Issue 4, 2020, Pages 1211-1217, https://doi.org/10.1016/j.asej.2020.02.001

AWAD, A.H.; EL-WAHAB, Abd.; ELGAMSY, Ramadan; ABDEL-LATIF, Hazen. Mechanical behavior of PP reinforced with marble dust.

Construction and Building Materials, Volume 228, 2019b. https://doi.org/10.1016/j.conbuildmat.2019.1 16766
AYDIN, Ertug; AREL, Hasan Sahan. High-volume marble substitution in cement-paste: Towards a better sustainability. Journal of Cleaner Production, v.237, 2019 http://doi.org/10.1016/j.jclepro.2019.117801

AZEVEDO, Afonso Rangel Garces; MARVILA, Markssuel Teixeira; BARROSO, Laimara da Silva; ZANELATO, Euzébio Barnabé; ALEXANDRE, Jonas; XAVIER, Gustavo de Castro; MONTEIRO, Sergio Neves. Effect of Granite Residue Incorporation on the Behavior of Mortars. Materials (Basel), 2019 http://dx.doi.org/10.3390/ma12091449

BAGHEL, Rupali; PANDEL, Upender; VASHISTHA, Apoorva. Manufacturing of sustainable bricks: Utilization of mill scale and marble slurry. Materials Today: Proceedings, v.26, 2020, 2136-2139 p. https://doi.org/10.1016/j.matpr.2020.02.460

BILGIN, N., YEPREM, H.A.; ARSLAN, S.; BILGIN, A.; GÜNAY, E.; MARŞOGLU, M. Use of waste marble powder in brick industry. Construction and Building Materials, v.29, 2012, 449$457 \mathrm{p}$.

http://doi.org/10.1016/j.conbuildmat.2011.10.011

BINICI, Hanifi; KAPLAN, Hasan; YILMAZ, Salih. Influence of marble and limestone dusts as additives on some mechanical properties of concrete.

Scientific Research and Essays, v.2, 2007, 372-379 p.

CHEN, J.J.; LI, B.H.; NG, P.L.; KWAN, A.K.H. Adding granite polishing waste as sand replacement to improve packing density, rheology, strength and impermeability of mortar. Powder Technology. v.364, 2020, 404-415 p. https://doi.org/10.1016/j.powtec.2020.02.012

CHIODI, Cid. O setor brasileiro de rochas ornamentais. Associação Brasileira da Indústria de Rochas Ornamentais, ABIROCHAS, 2018 
ERGÜN, Ali. Effects of the usage of diatomite and waste marble powder as partial replacement of cement on the mechanical properties of concrete. Construction and Building Materials, v.25, 2011, 806-812 p.

http://doi.org/10.1016/j.conbuildmat.2010.07.002

GHALEHNOVI, Mansour; ROSHAN, Naein; HAKAK, Erfan; SHAMSABADI, Elyas Asadi; BRITO, Jorge. Effect of red mud (bauxite residue) as cement replacement on the properties of selfcompacting concrete incorporating various fillers. Journal of Cleaner Production, v. 240,2019

http://doi.org/10.1016/j.jclepro.2019.118213

GONÇALVES, Jardel Pereira. Utilização do resíduo de corte de granito (RCG) como adição para a produção de concretos. Porto Alegre, 2000. 135f. Dissertação, Universidade Federal do Rio Grande do Sul - UFRGS, 2000.

INCE, Ceren; HAMZA, Ali; DEROGAR, Shahram; BALL, Richard James. Utilization of waste marble dust for improved durability and cost efficiency of pozzolanic concrete. Journal of Cleaner Production, v.270, 2020 http://doi.org/10.1016/j.jclepro.2020.122213

JAIN, Abhishek; GUPTA, Rajesh; CHAUDHARY, Sandeep. Sustainable development of self-compacting concrete by using granite waste and fly ash.

Construction and Building Materials, v. 262,2020

https://doi.org/10.1016/j.conbuildmat.2020.1 20516

KRSTULOVIĆ, P; KAMENK, N.; POPOVID, K. A new approach in evaluation of filler effect in cement I. Effect on strength and workability of mortar and concrete. Cement and Concrete Research, v. 24, 1994, 721-727 https://doi.org/10.1016/0008-8846(94)90197-X
LI, L.G.; HUANG, Z.H.; TAN, Y.P.; KWAN, A.K.H.; CHEN, H.Y. Recycling of marble dust as paste replacement for improving strength, microstructure and ecofriendliness of mortar. Journal of Cleaner Production, V.210, 2019, 55-65 https://doi.org/10.1016/j.jclepro.2018.10.332

LI, L.G.; HUANG, Z.H.; TAN, Y.P.; KWAN, A.K.H.; LIU, F. Use of marble dust as paste replacement for recycling waste and improving durability and dimensional stability of mortar. Construction and Building Materials, v.166, 2018a, 423-432 http://doi.org/10.1016/j.conbuildmat.2018.01.154

LI, L.G.; WANG, Y.M.; TAN, Y.P.; KWAN, A.K.H.; LI, L.J. Adding granite dust as paste replacement to improve durability and dimensional stability of mortar. Powder Technology, v.333, 2018b, 269-276 p.

https://doi.org/10.1016/j.powtec.2018.04.055

LÓPEZ, Gemma Rojo; NUNES, Sandra; FONTEBOA, Belén González; ABELLA, Fernando Martínez. Quaternary blends of Portland cement, metakaolin, biomass ash and granite powder for production of selfcompacting concrete. Journal of Cleaner Production, Volume 266, 2020. http://doi.org/10.1016/j.jclepro.2020.121666

MAHESH V. Patil; YOGESH D. Patil. Effect of copper slag and granite dust as sand replacement on the properties of concrete. Materials Today: Proceedings, 2021, 1666-1677p.

https://doi.org/10.1016/j.matpr.2020.10.029

MARTINI, Tcharllis Joao da Cunha; RODRÍGUEZ, Rubén Jesus Sánchez; SILVA, Fernanda Souza. Physical and mechanical evaluation of artificial marble produced with dolomitic marble residue processed by diamond-plated bladed gangsaws. Journal of Materials Research and Technology, v.7, 2018, 308-313 p. https://doi.org/10.1016/j.jmrt.2018.02.001 
MASHALY, Ahmed; SHALABY, Basel; RASHWAN, Mohammed. Performance of mortar and concrete incorporating granite sludge as cement replacement.

Construction and Building Materials, v.169, 2018, 800-818

http://doi.org/10.1016/j.conbuildmat.2018.03.046

MATOS, Paulo Ricardo; SAKATA, Rafael Dors; GLEIZE, Philippe Jean Paul; BRITO, Jorge; REPETTE, Wellington Longuini. Eco-friendly ultra-highperformance cement pastes produced with quarry wastes as alternative fillers.

Journal of Cleaner Production, v.269, 2020, 41-54 p.

http://doi.org/10.1016/j.jclepro.2020.122308

MEDINA, G.; SÁEZ DEL BOSQUE, I.F.; FRÍAS, M.; SÁNCHEZ DE ROJAS, M.I.; MEDINA, C. Durability of new recycled granite quarry dust-bearing cements.

Construction and Building Materials, v.187, 2018, 414-425 p.

http://doi.org/10.1016/j.conbuildmat.2018.07.134

MESSAOUDA, Belouadah; RAHMOUNI, Zine El Abidine; TEBBAL, Nadia.

Influence of the addition of glass powder and marble powder on the physical and mechanical behavior of composite cement.

Procedia Computer Science, v.158, 2019, 366-375 p.

https://doi.org/10.1016/j.procs.2019.09.064

MONTANI, Carlo. Marble and stones in the world XXVIII report - international situation production and interchange. Casa di edizioni in carrara, v.18, 2017, $1-132 \mathrm{p}$.

NASCIMENTO, Anny Salonny; SANTOS, Cochiran Pereira; MELO, Fernanda Martins Cavalcante; OLIVEIRA, Vanessa Gentil Almeida; OLIVEIRA, Rosane Maria Pessoa Betanio; MACEDO, Zélia Soares; HERBET, Hebert Alves. Production of plaster mortar with incorporation of granite cutting wastes. Journal of Cleaner Production, v.265, 2020 https://doi.org/10.1016/j.jclepro.2020.121808
NBR 11579: Cimento Portland Determinação do índice de finura por meio da peneira $75 \mu \mathrm{m}\left(\mathrm{n}^{\circ} 200\right)$.

Associação Brasileira de Normas Técnicas, Rio de Janeiro, 2013.

NBR 12655: Concreto de cimento Portland - Preparo, controle, recebimento e aceitação - Procedimento, Associação Brasileira de Normas Técnicas, Rio de Janeiro, 2015.

NBR 16372: Cimento Portland e outros materiais em pó - Determinação da finura pelo método de permeabilidade ao ar (método de Blaine). Associação Brasileira de Normas Técnicas, Rio de Janeiro, 2015.

NBR 16605: Cimento Portland e outros materiais em pó - Determinação da massa específica. Associação Brasileira de Normas Técnicas, Rio de Janeiro, 2017.

NBR 16607: Cimento Portland Determinação dos tempos de pega. Associação Brasileira de Normas Técnicas, Rio de Janeiro, 2018.

NBR 16697: Cimento Portland Requisitos. Associação Brasileira de Normas Técnicas, Rio de Janeiro, 2018.

NBR 16916: Agregado miúdo Determinação da massa específica e massa específica aparente, Associação Brasileira de Normas Técnicas, Rio de Janeiro, 2021.

NBR 5738: Concreto de cimento Portland - Preparo, controle, recebimento e aceitação - Procedimento, Associação Brasileira de Normas Técnicas, Rio de Janeiro, 2016.

NBR 5739: Concreto - Ensaio de compressão de corpos de prova cilíndricos, Associação Brasileira de Normas Técnicas, Rio de Janeiro, 2016. 
NBR 7211: Agregados para concreto Especificação. Associação Brasileira de Normas Técnicas, Rio de Janeiro, 2019.

NBR 9781: Peças de concreto para pavimentação - Especificação e métodos de ensaio. Associação Brasileira de Normas Técnicas, Rio de Janeiro, 2013.

NBR NM 14: Cimento Portland - Análise química - Método de arbitragem para determinação de dióxido de silício: óxido férrico: óxido de alumínio: óxido de cálcio e óxido de magnésio. Associação Brasileira de Normas Técnicas, Rio de Janeiro, 2012.

NBR NM 15: Cimento Portland - Análise química - Determinação de resíduo insolúvel. Associação Brasileira de Normas Técnicas, Rio de Janeiro, 2012.

NBR NM 16: Cimento Portland - Análise química - Determinação do anidrido sulfúrico. Associação Brasileira de Normas Técnicas, Rio de Janeiro, 2012.

NBR NM 18: Cimento Portland - Análise química - Determinação de perda ao fogo. Associação Brasileira de Normas Técnicas, Rio de Janeiro, 2012.

NBR NM 19: Cimento Portand Determinação de enxofre na forma de sulfeto. Associação Brasileira de Normas Técnicas, Rio de Janeiro, 2012.

NBR NM 20: Cimento Portland e suas matérias primas - Análise química Determinação de dióxido de carbono por gasometria. Associação Brasileira de Normas Técnicas, Rio de Janeiro, 2012.

SALMAN, Siddique; JEONG, Gook Jang; TRILOK, Gupta. Developing marble slurry as supplementary cementitious material through calcination: Strength and microstructure study. Construction and Building Materials, Volume 293, 2021. https://doi.org/10.1016/j.conbuildmat.2021.1 23474

THAKUR, Anil Kumar; PAPPU, Asokan; THAKUR, Vijay Kumar. Resource efficiency impact on marble waste recycling towards sustainable green construction materials. Green and Sustainable Chemistry, 2018 https://doi.org/10.1016/j.cogsc.2018.06.005

TORRES, P.; FERNANDES, H.R.; OLHERO, S.; FERREIRA, J.M.F. Incorporation of wastes from granite rock cutting and polishing industries to produce roof tiles. Journal of the European Ceramic Society, v.29, 2009, 23-30 p. https://doi.org/10.1016/j.jeurceramsoc. 2008. 05.045

ZANELATO, Euzebio; ALEXANDRE, Jonas; AZEVEDO, Afonso; MARVILA, Markssuel; XAVIER, Gustavo; MONTEIRO, Sergio. Evaluation of the Incorporation of Marble and Granite Residue in Coating Mortars. Advances in Powder and Ceramic Materials Science. The Minerals, Metals \& Materials Series. Springer, 2020, 101-108 p. https://doi.org/10.1007/978-3-030-365523_10 